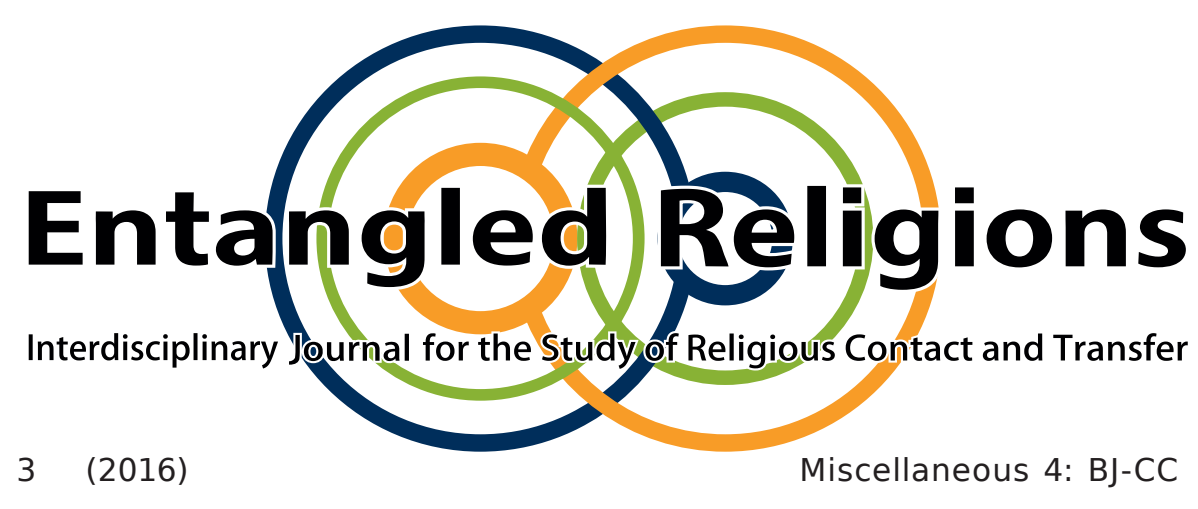

\title{
Religious competition: is it a useful concept?
}

\author{
FREDERICK G. NAEREBOUT \\ Department of Ancient History, Leiden University, The Netherlands
}

License:

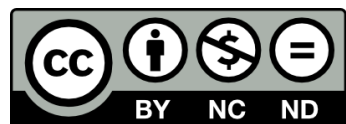

This contribution to Entangled Religions is published under the Creative Commons Attribution-NonCommercial-NoDerivatives 4.0 International Public License (CC BY-NC-ND 4.0 International). The license can be accessed at http://creativecommons.org/licenses/ by-nc-nd/4.0/ or is available from Creative Commons, 559 Nathan Abbot Way, Stanford, California 94305, USA.

(c) 2016 Frederick G. Naerebout ISSN 2363-6696
Entangled Religions 3 (2016) http://dx.doi.org/10.13154/er.v3.2016.BJ-CC
RUHR

UNIVERSITÄT

BOCHUM

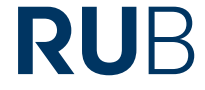

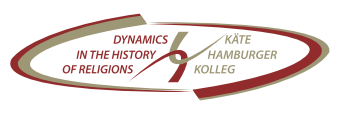

Federal Ministry of Education and Research 


\title{
Religious competition: is it a useful concept?
}

\author{
FREDERICK G. NAEREBOUT \\ Leiden University, The Netherlands
}

\begin{abstract}
In recent years 'competition' has become an ever more popular concept in the study of ancient religions. Or should that be a label? Innovative concept or mere label: to come to a decision, we should ask some questions. What are the studies that advertise themselves as dealing with competition about, what do people understand by it? Does competition do what it should be doing: provide some new interpretative framework, and, in the case of edited volumes, tie the different contributions together? In order to answer these questions, a fairly recently published volume (Rosenblum, Vuong \& DesRosiers, 2014) will be analyzed in some detail and compared to some other publications that cover (or seem to cover) the same ground.
\end{abstract}

KEY WORDS competition; rivalry; contestation; conflict; marketplace

\section{Competition}

It is interesting to observe how 'hot topics' come and go: syncretism, ritual, initiation, magic, identity, ethnicity, multiculturalism, otherness, individuality, power, globalization... to name some major concepts that in the field of the religious history of the ancient world over the past decades have come to the fore, have faded away again, or lingered on, concepts that have been put to work and have been debated-and which got papers published and projects financed. Scholarship is quite fashion-conscious, and this sweeps along even those who do not have a very good radar for picking up the latest trends. As it is only the happy few who are the first to apply a concept borrowed from whatever other discipline, or even come up with a new concept of their own, most scholars are consciously 
or unconsciously following a trend, hot on its heels or straggling behind. There are of course another happy few who can afford to neglect the trends that come by (we do not count those who never knew there was a trend in the first place), but most of us have rather less independent minds. Thus, when a buzz word pops up and stays around for some time, there is good reason to investigate. Has a new fashion arrived? And if so, should not we step back for a moment and look at it critically? Of course we should, but it is in the nature of trends and fashions to be accepted uncritically: we are indeed 'swept along'.

A concept that has been gaining ground for the past twenty years is that of competition (Olson 2002; Peters 2003; Beck 2006; Stark 2006; Engels \& Van Nuffelen 2014; Rosenblum, Vuong \& DesRosiers 2014; DesRosiers \& Vuong 2016). The "Religious Competition in Late Antiquity Unit" of the Society for Biblical Literature contributed papers to the annual conferences of the SBL in 2009-2014 which ended up in two of the above volumes. When we add (near) synonyms of competition, such as rivalry and contestation, and conflict as the possible outcome of competition, there is another crop of recent titles (Ascough 2005; Vaage 2006; Kahlos 2011). That the interest in religious competition is indeed a new departure, is argued explicitly in the introduction of the most recent volume mentioned above (DesRosiers \& Vuong 2016), and Engels and Van Nuffelen argue in their introduction that there is a general turn in the humanities from models that work in terms of social cohesion to models that posit competition as the basic structure of human society (Engels \& Van Nuffelen 2014). I doubt whether that is the case. It is fairly obvious that there has always been a lot of interest in the subject of religious competition in the ancient world, especially the confrontation between monotheists and polytheists, and between traditional cults and what Cumont called 'religions orientales', sometimes labelled as competition, more often as conflict, but usually under the guise 
of persecution, conversion, polemic, apologetics and so on. So partly it is just the labels that have changed. The frequent use of 'competition' and 'rivalry' is in itself something new: competition in the context of religion used to refer, nine times out of ten, to the presence of agones in some ritual context or to the elite vying with each other in munificence to sanctuaries and the like. Of course one still encounters the term 'competition' in those two contexts (because it need not be as label that it was used), but its usage has been shifting in another direction, with competition as the overarching framework for several forms of interaction between socioreligious groups competing for status, power or adherents. We have to ask again whether this has changed anything, and if so, whether it can be called an improvement.

\section{A test case}

In order to come to grips with these issues I want to turn to a recently published volume that seems to be of specific interest because it wants to do two things: focus on the third century, as a period that has been neglected; and look at competition within groups as much as between groups (Rosenblum, Vuong \& DesRosiers 2014). As to the attention paid to the third century, this is quite welcome, since most research has focused on early imperial days and on Late Antiquity, from Constantine onwards. For anyone interested in religious life in the third century in Italy and the eastern half of the empire there is much of value here. However, the way in which the material is approached is rather more important. There will always be some (relatively) neglected corner, and we can consider ourselves lucky when some light is shed on it-nevertheless, one should always ask whether it is more of the same, or whether it is discussed 
in a novel manner. Interestingly enough, this volume is not more of the same, because it is in large part (though not entirely) about intra-religious competition. The title of the volume does not really prepare the reader for this: it suggests (though admittedly it does not say so) that competition is something played out between Jews, Christians and pagans. In fact, much of the competition dealt with here is between Christians, between Jews, and between the one pagan and the other.

Of course, intra-religious tensions have been studied often enough, especially between Christians: the enormous subject of the rise of orthodoxy and thus of heresy. Jewish sectarianism drew less attention, but it is a recurring subject, although the political perspective tends to preempt the religious. Relatively little attention has been paid to competition between pagans. This is partly due to the confusion of competition and conflict (if one sees no conflict, then one concludes that there will have been no competition-while it is obvious that there need not have been any (open) conflict for bodies or persons to compete with one another). Here, ideas about the openness and tolerance of ancient polytheism also play a role. Those ideas have been subject to quite some criticism, but I think that in a general sense we can uphold the distinction between open polytheism and exclusivist monotheism (Engels \& Van Nuffelen 2014 argue for “intolerant polytheisms", but their example, present-day Hinduism, cannot be used to illuminate the workings of polytheism in the ancient world: the ideology of modern Hinduism is much shaped by 19th-century social Darwinism, racism and nationalism). In order not to lose ourselves in discussions about the examples where polytheist communities in the ancient world showed themselves rather less tolerant, it should be clear that the openness concerns above all the choices that are made by the individual. The very fact that there is a relatively large freedom of choice, and many religious phenomena to choose from, could lead the providers of religion, such as 
sanctuaries, to enter into competition with each other. This is something we will have to come back to. For the time being, it seems that the attention paid to intra-religious competition in the volume which is put central here is rather different from what we see in other publications on religious competition and that the interest in pagan intra-religious competition might even break some fresh ground.

The volume under discussion is a rather slender one, with 210 pages of text, consisting of an introduction and 17 short papers between 8 and 13 pages in length. The contributions are divided about equally (6-5-6) across three sections: "Assessing competition, methodology and approaches"; "Competition and ritual space and practice"; and "Modes of competition". The authors are an all American company, except for Andrew McGowan (Melbourne) and Gregg Gardner (Vancouver, but with a US background). They are mostly young scholars working, at the time of publication, at minor universities in the States, except for Ross S. Kraemer, emerita of Brown University (neither my mention of their relative youth, nor of the status of their employers are meant to disparage their quality as researchers: several have been educated at Brown, Harvard and Princeton). The authors have been members of a group interested in "the intersections of the diverse intellectual and religious traditions of the third century" (p. 10) which got together at the Annual Meeting of the Society of Biblical Literature. The 17 papers collected here represent the fruits of their gatherings in the years 2009-2011. All contributions are examples of trusted scholarship, wellannotated, leading on to a myriad of details that one might like to pursue. But however learned each of these papers may be, the volume as a whole also invites criticism. 


\section{The missing theoretical framework}

The introduction is rather inadequate: it gives excellent summaries of the individual contributions, but does nothing to tie the volume together. This is not to say that the volume is the loose collection of papers that is only too common. The focus on the third century and a set of recurring themes (to which we will come back below) give the volume a reasonable degree of coherence-which would have been even better if not five papers had dealt exclusively or largely with other centuries than the third (Urbano, Latham, Finkelstein, Krulak, Kraemer). However, the introduction should have gone into the concept of 'religious competition'. What do we understand by those words? In what ways has competition been studied? Is that done differently here? Is there anything specific about such competition in the third century? Important questions, but never asked, or discussed in unsatisfactory terms (e.g., saying that the third century is important because it did influence developments in the fourth century and beyond, seems an argument that holds good for any period of time, and that is also in need of an analysis that shows us what and how).

The volume advertised as the companion volume to the one under scrutiny here (DesRosier \& Vuong 2016) shares two editors with the latter volume. It contains a bit more theory, but this consists in a single reference to Bourdieu to the effect that competition should be seen as everybody trying to gather as much cultural capital as possible in the symbolic market place. While that surely makes more sense than looking at competition as 'who is better' (but who does? As so often, a caricature of previous studies is presented, in order to highlight the innovative nature of one's own approach), it does not say very much if one does not show how this works. Without any explanation of the mechanics 'cultural capital' and 'symbolic market place' must remain hollow phrases. 
What is quite surprising is the complete and utter silence about a longterm debate in religious studies between advocates and detractors of the so-called 'rational choice approach'. There, the idea of competitiveness across the whole religious spectrum, between different denominations and between different 'blood groups', different sanctuaries or different religious leaders, was very much at the heart of theory. The religious life of a community is seen as a religious marketplace where customers choose from what is on offer. This approach was much criticized, and is now usually spoken of as a short-lived aberration, happily discarded. Its most important champions, however, are still very much alive and are not ready to give in. They do stress repeatedly that they do not embrace all of the rational choice theory as this was formulated within economics and that they do take into account the specific nature of religion, but their detractors happily carry on criticizing without really addressing the arguments brought forward. The vehemence with which rational choice proponents are attacked, I can only explain from the fact that some people find the use of economic and social-psychological terminology so distasteful that they do not want to discuss it at all. I cannot help thinking that-whatever the merits of the specific applications of the theory (and I do not want to get involved in, say, the debate on modern day secularization) - the basic idea of the religious market place has quite some explanatory power, especially when we are dealing with polymorphous, polytheistic religions sharing the same space and time-as was increasingly the case in the Hellenistic kingdoms and the Roman empire.

What an introduction to the subject of competition could, and should, look like can be found in Engels \& Van Nuffelen, 2014. Much of what they say I find problematic, but at least we have here a discussion of why we should look at competition at the first place. If I may be allowed a little excursus: Engels and Van Nuffelen argue that as religion is entangled with 
social life, politics and so on, and since we find competition everywhere, in all of these aspects of society, there is always religious competition. I find this rather unsatisfactory: it is too unspecific. I think that any study which addresses religious competition should try to isolate specific instances of religious competition. Engels and Van Nuffelen would argue that due to the embeddedness of religion in ancient societies this is not possible-except maybe as a mental construct. Now, first of all, anything we say in the way of any analysis of the ancient world is a mental construct. Second, I look at embeddedness in a different way: not religion is embedded within ancient society, but ancient society, and that implies all aspects of it, is embedded in religion: ergo, ancient religion is fundamentalist. There is no aspect of human life that can be seen as distinct from ancient religious life. It is therefore obvious that competition is whatever field will have a religious component. But the fact that society is embedded in religion, means that there can also be something like religious competition in a more restricted sense: not a by-product of competition in another field, but competition that arises from the way religion is structured. That this last form of competition may have economic and social drives and consequences, I am the last person to deny. The point is that the competition itself emanates not from economic or social forces, but from the religious infrastructure itself.

Here we come back to the rational choice approach: it is there that you will find competition explained as a truly religious phenomenon. True to their approach, Engels and Van Nuffelen reject the whole idea of ancient religion as a market place: as a metaphor they find it workable, but now that it has been reified, they consider it all wrong. Though I want to praise Engels and Van Nuffelen for paying so much attention to the rational choice approach and the market place metaphor or model in their introductionwhich shows an awareness of the historiography of the concept lacking in the volume under review here-I think they should not so easily reject the 
market place model (it is not a metaphor, it is a model-which is different again from reification). Even Naerebout, 2009 is adduced to show how polytheism is often restricting access to cultic activities, instead of trying to mobilize a maximum audience. This is a misreading of what I have been arguing in many publications over the years. It has been too often said that 'the people', 'the polis', 'the citizens' did something, 'they sacrificed', 'they partook in the festival', 'they went in procession to the sanctuary', while there are obvious restrictions: we are dealing with territories with boundaries where numerous rules for inclusion and exclusion apply, rules which can be enforced or which people will internalize. But there can still be competition between the one sanctuary only open to women dressed in white with their hair loose and barefoot, and the other sanctuary-with the same rules, slightly different rules, completely different rules or hardly any rules at all. The basic fact is that people have limited resources: time, energy, money... and they can be in only one spot at any given time. Where do they go, what do they spend their resources on? Important questions in a world where the religious choices are myriad, you are mostly free to do as you please, and where, if you are not that rare elite member, you have but little time and money to spend. Cults and sanctuaries survive as long as people come. They will compete for mobilizing that audience (and, of course, for a great many other reasons).

\section{The individual papers}

Back to our volume: undoubtedly, the authors have been presenting papers on competition in third-century religion over the course of three years at their annual meetings without any idea about how their papers would be categorized or grouped together. For this volume, as we have seen, the 
editors have grouped the papers in three sections. Such ex post facto categorizations hardly ever work, and I do not think they work here. The first section is supposed to deal with questions of theory and methodology. In fact, only two papers deal explicitly with theories that might help in understanding or explaining forms or aspects of competition: Ullucci uses the cognitive science of religion to argue that counterintuitive religious knowledge has to be taught by religious experts, who in this manner enter into competition with each other, and who make themselves indispensable at the same time. McGinnis invokes Bourdieu's notions of habitus and of cultural capital, in order to show how philosophers try to put themselves in positions of authority, also in competition with church officials.

Larson and McGowan are not so much about theory, but ask about concepts, viz. tolerance and sacrifice. Larson's spirited argument that tolerance is a modern concept, developed from Spinoza, Locke and Bayle onwards, and not applicable to the ancient world, fails to convince. The intolerance he sees instead (should not that concept be inapplicable as well?) is, in polytheistic societies, very much an intolerance in political discourse and sometimes in political action, much different from the exclusiveness based in religious thought which we see in monotheism. That Romans reject Celtic religion because of human sacrifice, one of Larson's examples, is not true, as we all know that Celtic gods were welcomed into the pantheon. That elusive entity 'Roman religion' does embrace 'Celtic religion' (hardly less elusive a category). It is true that Romans reject human sacrifice, certainly if practiced by the barbaric 'Other', but they do not reject anything whatsoever because of it. McGowan argues that 'sacrifice' is a construct, which as such, is undoubtedly true. His idea that there are many different ways in which different people deal with sacrifice, and that in that process sacrifice itself changes meaning, seems reasonable 
enough. Whether in this manner he "re-theorizes" (p. 70) anything, as he states, I cannot see.

Rosenblum and Ullucci, on the other hand, in the second section, bring up theory explicitly again, once more cognitive science, here used to enlighten food laws in the Mishnah. The many regulations concerning food are not random, but are the result of mundane activities such as food preparation being treated as ritual occasions. In ritual the status of the agent is a crucial element; by turning food preparation into a ritual, the status of the individual preparing the food becomes all important. The paper by Kraemer on gender I would also like to include with the theoretical/methodological ones: it is an excellent overview of issues of the gender of agents partaking in competition, and of the gendering of competition itself and of the competitors themselves, e.g. asserting that one's opponents are female or manipulated by females, or deriding one's male opponents as feminine.

The two papers remaining in the first section (Marx-Wolf and Urbano) deal with philosophy. Porphyry and lamblichus use Pythagoras as a canvas on which to project their own ideals. Numenius, Porphyry and Eusebius present a narrative of decline comparable to that of Hesiod, and present themselves and their entourage as renewers of a golden age. This is about competition amongst Neoplatonists, pagan and Christian. Porphyry and lamblichus recur throughout the volume, as does the main issue of contention between the two: sacrifice. Klein speaks of the competition between rabbis at Sepphoris and Tiberias-interestingly, he does so in spatial terms: when competitors gain ground, the centre of gravity moves from the one urban centre to the other. Krulak comes back to the competition between Porphyry and lamblichus, how it was carried on into the fourth century by Maximus and Eusebius, and how these opposing factions were brought together by Damascius. A rather special case is dealt 
with by Latham, where the Christian elites of Rome oppose the bishop of Rome and manage to keep a hold on public space by adhering to a pagan festival calendar until well into the 6th century. That the different factions amongst the Roman Christians should have turned to violence as their only outlet because there were no other opportunities to make themselves seen or heard, I do not find quite convincing.

Others have turned to inter-religious competition. Gardner discusses euergetism, and shows how rabbinic sources appropriate euergetism by changing its raison d'être into piety and a sense of religious obligation, and by stressing immaterial instead of material rewards. This is an interesting subject and should definitely be pursued further. I personally doubt whether the rewards for a gift-giver in pagan society were always so material. The immaterial plays its part, especially when there are mere costs rather than rewards, just as the wish to be memorized is found with Jewish benefactors. DesRosiers has produced an interesting account of oath taking, central to ancient society, but something shunned by Christians (or supposed to be shunned by them; DesRosiers states that most Christians probably retained the practice of taking oaths-but if this was the case, it rather undermines his account). Christians than appropriate oath taking, especially the sacramentum, and turn it into their very own sacrament of baptism. Vuong shows how the Second Temple, after its destruction, continues to be used as a symbol by Jews, Christians, and, remarkably, Romans. Finkelstein focuses on the Emperor Julian, and how he uses the readiness of Jews to die in defense of their ancestral law to undermine Christian martyrdom-a very special case in inter-religious competition. Berzon looks at heresiology, more specifically that of Irenaeus and of Epiphanius, who create a new ethnography wherein Christianity is the organizing principle of the world: of course this is also an example of interreligious competition, but again a rather special case. Largely lacking is the competition-and outright 
conflict-between Romans and Christians. It is somehow strange to have a volume with the present title, focusing on the third century, and to find next to nothing on the persecution of the Christians in that century.

Stern, in one of the most interesting papers of the volume, discusses competition within pagan, Jewish and Christian circles as played out in everyday life by common individuals. For this connection to everyday life we were prepared by Gardner on euergetism and DesRosiers on oath taking, very much facts of life in any ancient community-but both foregrounded discourse without ever really progressing to the question what this discourse implied for actual gift giving and swearing of oaths. Stern discusses graffiti and dipinti in the temple of Aphlad, the Mithraeum, the Synagogue and a Christian place of worship in Dura Europos. Believers have left their names and invocations of the god(s) scratched and painted on walls, vying for attention by getting closer to a statue or painting, or by repetition or by lettering. This paper I find so interesting because it addresses head on what in other papers is not mentioned at all or only hinted at: "it is likely that most Christians continued to take oaths as a matter of everyday necessity" (p. 94), or "these texts probably do not reflect real Jewish practices in the third century" (p. 105). It is, however, a great pity that Stern seems unaware of the article by Lucinda Dirven on exactly the same issue, which dates from well before even the first papers presented by the SBL Competition Unit (Dirven 2004).

Of course as far as 'real life', 'lived religion' is concerned Ullucci gives rather more than a hint with his insistence on the $99 \%$-but here the application of cognitive studies pre-empts any discussion of reality in terms of observable reality (as in Rosenblum and Ullucci, where the questions about description versus prescription, and about ritual as opposed to the description of ritual are answered by reasoning that it should be possible to trace whatever is rooted in cognition in both the real and the imagined 
world-in some unspecified measure. This is as true-in some measureas it is unhelpful). Stern firmly rejects a literal reading of our sources, unless we can make a case that we really have people competing with one another. Her analysis of the Dura Europa inscriptions is a case in point. With Stern we can, and must, say that we need a very strict source criticism if we want to relate what philosophers, religious experts and the like tell us, to real life events. This relationship between reality and discourse is queried explicitly in several papers in Engels \& Van Nuffelen 2014. One of the outcomes of such careful attention being paid to reality on the ground is that in the ancient world there was not just religious competition, but also a large amount of religious accommodation and collaboration. In that way, it is myopic to speak of competition only (see Lightstone 2005, who refers to Leif Vaage's seminal paper of 1995, unpublished but much quoted, and afterwards incorporated into Vaage, 2006).

\section{Summing up}

When the editors of Rosenblum, Vuong \& DesRosiers 2014 state that what happened in the third century is interesting for its own sake, I think one can only agree. If they say it is interesting because these goings-on were so influential beyond the third century that is a truism. If they say the case studies contribute to the development of "methodological frameworks" ( $p$. 17) for the study of competition, I think I have to disagree. The editors have not attempted anything in this way, and what some of the authors contribute is too little and too fragmented to add up to one or more frameworks for further study. Theory, model making, method... the discussion of all of this is extremely insufficient; that the debate on competition in religious 
studies of the past decades is completely neglected, is something that really discredits the collection-despite its interesting papers.

Most seriously, when the editors stress that this volume deals with momentous developments and conflicts that "drastically changed the social and religious landscape of the Roman world" (p. 10, my emphasis), one cannot but conclude that the social has been overlooked or has been excluded from this collection. These are studies, fine studies when looked at in isolation that are very much turning inwards, looking at religious competition from the angle of the intellectual discourse only. Not that I should want to urge neglect of such discourse: it is as much part of history as the graffiti of Stern, or the 137 people slaughtered in the basilica of Sicininus by the thugs sent out by pope Damasus as discussed by Latham, but the crux here are of course the words part of: where in this volume is the third-century Roman empire, its people, its society, its politics, as the background against which the religious competition is played out? How strange that no reference at all is made to literature on the socalled crisis of the third century: no Geza Alföldy, no Luuk de Blois, no J.H.W.G. Liebeschuetz; A.H.M. Jones could not not be mentioned, but he is quoted about heresy only; Peter Brown and Ramsay MacMullen figure in the bibliography as well, but again not their works on the third century. Incidentally, none of the volumes on religious competition mentioned above are referred to, so even the English-language bibliography seems extremely incomplete, not to speak of an extensive German literature: Joachim Molthagen, Johannes Hahn, Stefan Koch, Jörg Rüpke...

And now our main issue: has the focus on competition, in the present and other volumes, brought with it an innovative interpretative departure? A nuanced answer seems called for. That we have moved from studies which focussed on the narrower aspect of conflict to a much wider field, which can also include intra-religious competition (and here the volume 
under scrutiny really makes a contribution), certainly opens our eyes to the way in which all sorts of competition, rivalry and conflict interconnect. Also, we can link up with recent studies of competition other than religious competition-which are also widening their scope and moving away from the restrictive idea of agonistic societies. On the other hand, I think one of the problems with the whole concept of competition, especially if taken so broadly as to embrace everything from the believers competing for the attention of the $\operatorname{god}(\mathrm{s})$, religious leaders or experts competing for the attention of the believers, and believers of one creed competing with the believers of another, whether it is about inter- or intra-religious competition, is that it seems very much a fact of life. In its actual shape competition will be very much dependent upon the society in question (an isolated village in the middle of nowhere is not a cosmopolitan city in an imperial setting), but competition will be present in at least one of the above forms. As if we have moved from 'the agonistic nature of ancient society' to 'the agonistic nature of all society'. If we want competition to be more than a mere label replacing previous labels, if we want it to be a concept that guides our research in a meaningful way, we have to cherish the scope of the concept, and at the same time guard against extending that scope so far as to end up with truisms. That balancing act can be performed by having recourse to a proper theoretical framework that is not only referred to, but that is put to use. I personally think that the rational choice theorists have something on offer that might do the trick. I think it might have given the volume reviewed here a twist that could have turned it into a trailblazing book, instead of a set of nice papers largely of interest to specialists. But I am open to all other suggestions. 


\section{Reference List}

Ascough, R.S. ed. 2005. Religious rivalries and the struggle for success in Sardis and Smyrna, Waterloo, ON: Wilfrid Laurier University Press.

Beck, Roger L. 2006. "The religious market of the Roman empire: Rodney Stark and Christianity's pagan competition." In Religious Rivalries in the Early Roman Empire and the rise of Christianity, edited by L.E. Vaage, 233-252. Waterloo, ON: Wilfrid Laurier University Press.

DesRosiers, Nathaniel P. \& Lily C. Vuong. eds. 2016. Religious Competition in the Greco-Roman World. Atlanta: SBL Press.

Dirven, Lucinda. 2004. "Religious competition and the decoration of sanctuaries. The case of Dura Europos." ECA 1: 1-20.

Engels, David \& Peter Van Nuffelen. eds. 2014. Religion and competition in Antiquity. Bruxelles: Éditions Latomus.

Jacobsen, Anders-Christian, Jörg Ulrich \& David Brakke. eds. 2009. Critique and apologetics : Jews, Christians and pagans in Antiquity. Bern: Peter Lang.

Kahlos, M. 2011. The faces of the Other. Religious rivalry and ethnic encounters in the later Roman world, Turnhout: Brepols. 
Lightstone, Jack N. 2005. "Urbanization in the Roman East and the inter-religious struggle for success." In Religious rivalries and the struggle for success in Sardis and Smyrna, edited by R.S. Ascough, 211-244. Waterloo, ON: Wilfrid Laurier University Press.

Mayer, Wendy \& Bronwen Neil. eds. 2013. Religious conflict from early Christianity to the rise of Islam, New York: De Gruyter.

Naerebout, F.G. 2009. "Territorialität und griechische Religion-die aufgeteilte Landschaft." In Die Landschaft und die Religion, edited by E. Olshausen \& V. Sauer, 191-214. Stuttgart: Franz Steiner Verlag.

Olson, Daniel V. A. 2002. "Competing notions of religious competition and conflict in theories of religious economies" In Sacred markets, sacred canopies: essays on religious markets and religious pluralism, edited by Ted G. Jelen, 133-166. Lanham: Rowman \& Littlefield.

Peters, F.E. 2003. The monotheists: Jews, Christians and Muslims in conflict and competition, Princeton: Princeton University Press

Rosenblum, Jordan D., Lily Vuong \& Nathaniel DesRosiers. eds. 2014. Religious competition in the third century CE: Jews, Christians, and the Greco-Roman world, Göttingen: Vandenhoeck \& Ruprecht.

Stark, Rodney. 2006. "Religious competition and Roman piety." Interdisciplinary Journal of Research on Religion 2: 1-30. 
Vaage, L.E. 2006. Religious rivalries in the early Roman Empire and the rise of Christianity, Waterloo, ON: Wilfrid Laurier University Press. 